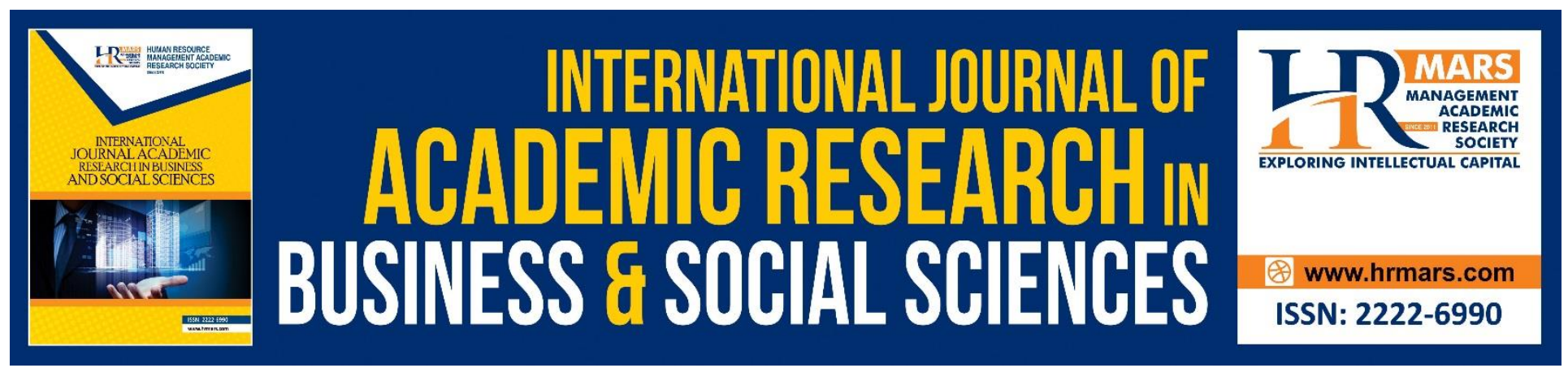

\title{
Constructing Authentic Experience and Psychometric Model in Influencing Sense of Community Among Volunteer
}

\section{Norol Hamiza Zamzuri}

To Link this Article: http://dx.doi.org/10.6007/IJARBSS/v8-i11/5281

DOI: $10.6007 /$ IJARBSS/v8-i11/5281

Received: 19 Oct 2018, Revised: 25 Nov 2018, Accepted: 29 Nov 2018

Published Online: 03 Dec 2018

In-Text Citation: (Zamzuri, 2018)

To Cite this Article: Zamzuri, N. H. (2018). Constructing Authentic Experience and Psychometric Model in Influencing Sense of Community Among Volunteer. International Journal of Academic Research in Business and Social Sciences, 8(11), 1581-1588.

\section{Copyright: (c) 2018 The Author(s)}

Published by Human Resource Management Academic Research Society (www.hrmars.com)

This article is published under the Creative Commons Attribution (CC BY 4.0) license. Anyone may reproduce, distribute, translate and create derivative works of this article (for both commercial and non-commercial purposes), subject to full attribution to the original publication and authors. The full terms of this license may be seen at: http://creativecommons.org/licences/by/4.0/legalcode

\section{Vol. 8, No. 11, 2018, Pg. 1581 - 1588}

Full Terms \& Conditions of access and use can be found at http://hrmars.com/index.php/pages/detail/publication-ethics 


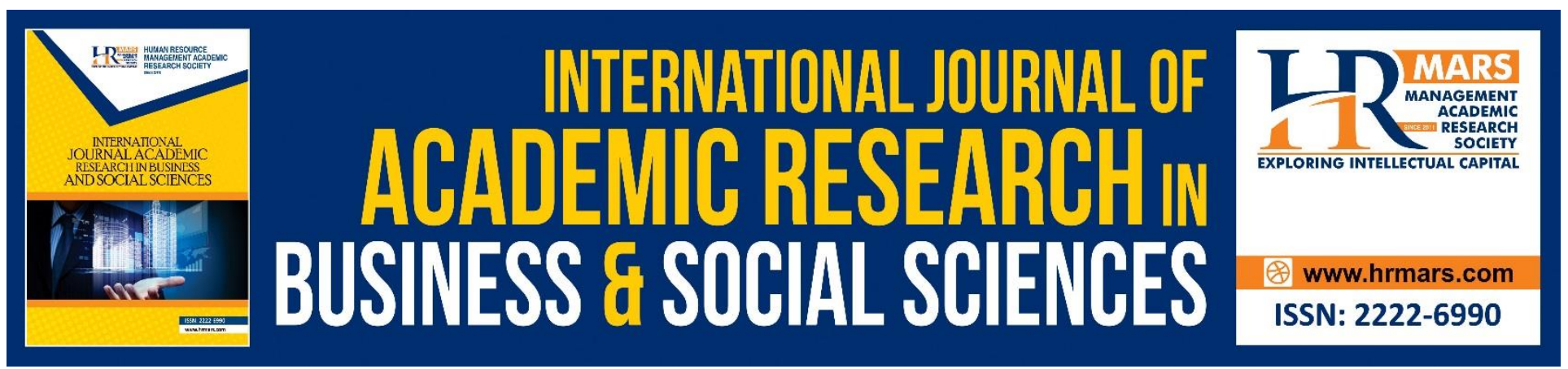

\title{
Constructing Authentic Experience and Psychometric Model in Influencing Sense of Community Among Volunteer
}

\author{
Norol Hamiza Zamzuri \\ Faculty of Business and Management, Universiti Teknologi MARA, 40300 Puncak Alam, \\ Selangor \\ Email:norol@puncakalam.uitm.edu.my
}

\begin{abstract}
The aim of this article is to review on authentic experience, pschometric element in shaping the sense of community among volunteer during an event. It reviews based on 18 articles that related to the term of authentic experience, pschometric,sense of community and sustainable event. The discussion compounded on the area of sport event as most of literatures are focusing on this event, however, it seems that there is spaucity of discussion on volunteer managmeent and sense of community. Atlast i software generate the theme found from reviews. Thus, this paper is only reviewing from literature, therefore, it is highly demand to explore on the depthness of these factors toward instilling sense of community among volunteer.
\end{abstract}

Keywords: Event Experience, Sport's Event, Volunteer, Pschometric, Sense Of Community

\section{INTRODUCTION}

Sense of community community (SOC) describes people's perception of their experience within the community (Winkle \& Woosnam, 2013). SOC was discussed by scholars from several areas such as hospitality, healthcare and education (Lampinen et al. 2015; Winkle \& Woosnam, 2013). It is a concept that based on psychological sense of community that construct for community psychology and other disciplines of community research (Peterson et al., 2008, cited in Lampinen et al. 2015, p. 228). Sense of community among society is important as to achieve the aim of sustainable event concept as the feeling of belonging result positive social impact.

Social impact is one of the pillars for sustainable development (Winkle \& Woosnam, 2013). Sustainable or also known as preserving the ecology (Baker, 2006) not only emphasize on green but also highlighting three important event pillars namely social, economic and environment (C.SmithChristensen, 2009), thus these pillars illustrating the definition introduced during in Brundland Report 
that is: preserving the environment as result from development (Baker, 2006), hence as the growth of development, this definition also widen up the meaning by including other elements as result from development.

Event's stakeholders involves with spectators, event's attendees, community, volunteer and others (Reid, 2011). Among these stakeholders, volunteer management attract attention among scholars due to the relationship between social and community service, as volunteering service is related to the sociological and psychological views and it more on focusing on social and community services (Coyne \& Coyne, 2001; Gallarza, 2000; Strigas \& New-ton-Jackson, 2003, p. 108, cited in (Gallarza, Arteaga, \& Gil-Saura, 2013).

For the past few years, there are debates on volunteering management hence, the discussion on volunteer psychometric in explaining volunteer commitment to volunteer is still relatively lacking (Giannoulakis et al. , 2015) and there is still a need to understand the phenomenon of volunteer management as most of past studies were not articulated a theoretical framework by engaging with relevant theory in order to better understand and predict on volunteer management strategies in building up a sense of community among volunteer (Kim, et.al, 2017).

Therefore, the aim of this study is to discuss on possible issues that related to volunteer management strategies in building up a sense of community among volunteer that shape the sustainable process of an event. The discussion in this article begin with an overview of event management sector as this study is only focusing on issues in this area, secondly the discussion will be elaborating the sustainable event, due to give a better view on how volunteer management shape the one of sustainable component namely social impact of an event, thirdly in explaining issues related to volunteer management, the dimension of volunteer experience is highly concerned as there is still a demand for researcher in exploring volunteer strategies especially in the context of volunteer experience specifically pschometric views. Yet, the inclusion of sense of community is highly referenced in this discussion as there is a demand to understand the role of volunteer experience that shape sense of community among volunteer. Lastly, the discussion in this article end up with the summarizing views on the whole context of the main issue that that discussed in this study.

\section{LITERATURE REVIEW}

Event management sector is one that has contributed immensely to the economy and is responsible for increasing the revenue in the tourism industry. In Malaysia, business events potentially yield more than a hundred times the return per Ringgit from government investments in events that have been organized in Malaysia (PEMANDU, 2015). As of December 2012, 45 major business events had been secured, attracting a total number of 61,659 delegates and raking in an estimated revenue of RM597 million (PEMANDU, 2012). Thus, this reveals that there is demand for organizing event in Malaysia, and this created social impact and generate income revenue from the growth of this sector. 


\section{Sustainable Event}

Economic, social and environment are also known as three pillars in event (C.Smith-Christensen, 2009) and is known as Triple Bottom Line (Sherwood, 2007). It is also known as important component for a sustainable event (Zamzuri, 2016). The discussion on sustainable event was formally discussed in drivers and barriers model that were developed by Mair and Jago (2010) that aimed to create a general conceptual framework to understand the process of corporate greening an underpin the development to enhance greening. The model represents the interconnections between the dimensions that are influential and also includes both the organizational context of the individual firm and the role of the media in setting the agenda for the salience of environmental issues. The model proposes that competitive advantages, image enhancement, supply chain/customer corporate social responsibility policies and consumer demand are significant drivers of greening. The barriers of greening an event are lack of time, lack of resources, lack of knowledge/awareness/skills and operational timeframe. However, this study is sketchily conceptual and only focusing on drivers and barriers. This is because, as mentioned earlier, sustainable event also involves economic, environment and social dimensions. Among these dimensions, it seems that the discussion on social impact from the view of volunteer management is relatively lacking (Kim, et. al., 2017). The discussion on volunteer management especially on experience is mostly observed, hence, the inclusion of psychometric and volunteer experience in explaining the relation between volunteer commitment and sense of community as social impact is vital to understand the phenomenon of volunteer management and sense of community among volunteer.

\section{Volunteer Experience}

Experience is defined as psychological cognitive state or each evaluation object is vary according to its own meaning, it relates with store mental representation or also known as stimulate (Osgood, Suci \& Stanabaum, 1957, cited in Kaplanidou \& Vogt 2010, p. 546), and used to stimulate and interpret.

For the past few years, there are several areas of studies that elaborated and explored the role volunteer experience in sports Event. Lee et al. (2015) are concerns on the use of online media as social interaction tools. Social interaction affects team member exchange and as result predict volunteer commitment to do volunteering service. Interestingly, Mykletun and Himanen (2016) found out that volunteering behavior also relates with the an individual cognitive namely egoistic, altruistic, connection to sport event and other external factor that motivate volunteering motivation to remain volunteer in the future. There are few studies discussed on the factors that motivate events volunteer. Hallmann and Harsm (2012), found that volunteer engagement is much related to earning for an expression of value and personal growth, hence, the containment of factors are different according to its own type of event. Giannoulakis et al. (2015) embrace the difference types of motivation factors according to satisfaction, motivation and experience, hence, the discussion on these factors is relatively lacking. Interestingly it found that there is demand to further investigate other experience dimension and emphasizes on the role of psychometric properties in determining the phenomena between motivation, experience and satisfaction. 


\section{Authentic Experience Theory}

In explaining volunteer experience, authentic experience theory is highly referenced. The concept of authentic experience is operationalized as the feeling of using genuine items of a product or a service (Kim \& Jang, 2016) and this concept mostly discusses in service industry (Kim \& Jang, 2016). For the past few years, there are several theories used in explaining authentic experience related to marketing, information system and management. Gilmore and Pine's theory is the most well-known theory that highlights on two important concepts on whether the product or experience are true and whether the experience are what they claim in relation to the other (Kim \& Jang, 2016). This theory was used in the study of Hede (2014) who describes that the concept of authenticity involves with individual perception on their expectation, skepticism, customer, firm, products or materials, satisfaction and hypotricy.

The description on the concept of authenticity by Hede et al. (2014) a line with the concept mentioned by Gilmore and Pine's on the importance of reviewing individual perception based on what they feel and what they share with other.

\section{Psychometric Properties}

Psychometric is used to measure human behavior by using an instrument (Lord \& Lord, 1993). One of the examples is used in in Big 5/five factor model. The assessment is based on extraversion, agreeableness, Conscientiousne, Neuroticism and openess (Kadri, 2013). Interestingly, in the study of Andreassen (2014), the authors applied three assesments in evaluating workaholism. The assesement are Workaholism Battery (WorkBAT), the Work Addiction Risk Test (WART) and the Dutch Work Addiction Scale (DUWAS).

\section{METHODOLOGY}

Atlast-I software was used in segmenting the theme and code reveal from reviews. There are 30 articles were reviewed in this study.

\section{DISCUSSION}

The disclosure of sustainable event containment of economic, environment and social is important for country development as result from the growth of event industry. A generating income revenue and community impact as result from organizing event open up more opportunities for the involvement of all event's stakeholder in accommodate the demand of event. Hence, there is demand for understanding the involvement of volunteer during event as it found that the main motivation factor for volunteering commitment is no more for tangible reward but more on gaining value such as feeling to be part or contributing to certain event, or feeling of important.

The involvement of volunteer especially for community service is vital as to uphold the aim for sustainability development. Thus one of the component for sustainable pillar is society, therefore, the involvement for volunteering in shaping their sense of community is deem important to ensure the aim for sustainability development is achieved via this engagement. 
The involvement of volunteer engagement for community service is much related to several factors. Upon the above discussion, the volunteer involvement is much related to an individual background from it own psychometric components. This results from an individual personality, differences addictive behavior and several other factors.

There are several individual psychometric such as age, background, cognition and personality type. These elements may result in shaping an individual experience especially on belief and event experience expectation. Each volunteer may result difference belief as it depends on individual background and cognitive ability, thus these factors may influence the sense of community as result from volunteer commitment during an event.

Apart from this, a dipper understanding is demand especially for determining an individual emotional feeling as these depends on their authentic experiential feeling during their involvement of the event. This is because; each individual has its own perception and belief on their volunteering involvement. The authentic experience for each volunteer is different, as it depends on their age, background, personality and other contributing factors of determination for volunteering commitment.

In explaining the phenomenon, several theories were discussed from the above discussion. Authentic experience theory is highly referenced as it provides an explanation on the role of individual belief on their actual experience and their expectation, thus it is postulates that an individual actual experience play a role in influencing their expectation. Volunteer expectation on their actual experience also shape their commitment for volunteering service in the future, thus this result a sense or inner feeling of belonging as part of a community. This is explain in Theory of Reasoned Action, which emphasizes on the role of positive attitude toward an action, therefore, the positive attitude as result from achieving an individual expectation may influence an individual behavior for volunteer engagement in the future. This may result of feeling of sense of belonging to the community.

\section{CONCLUSION}

In conclusion, this article elaborates on several terms that highlighted in this study. It begins with the discussion on sense of community, as it became the main discussion in this article. Sense of community is seen as an important element of sustainability development as result from the view of social impact. The debates and discussions by scholars highlighted the gap of the discussion of this issue in the study of volunteer management. This is because, it observes the volunteer is an important event's stakeholders that demand further understanding. This is especially in providing understanding their motivation and commitment as different volunteers have its own segment of background and this lead to their main motivation of volunteer.

Several motivation are identified for driving the volunteer engagement as volunteer for any community activities, hence although much has been debated on motivation factors, it seems that there is a need to explore on the interlink between satisfaction, experience, motivation and psychometric properties, thus this result for further discussion for future research. The debates on 
INTERNATIONAL JOURNAL OF ACADEMIC RESEARCH IN BUSINESS AND SOCIAL SCIENCES

Vol. 8, No. 11, Nov, 2018, E-ISSN: 2222-6990 @ 2018 HRMARS

volunteer management also result a demand for exploring volunteer strategies in building up sense of community among volunteer, therefore it is also suggested that future researchers should explore more on this phenomenon.

The debates on volunteer management also shows a need to conduct an in-depth study of understanding the phenomenon of volunteer management or engagement as most studies are focusing in testing a theory rather than developing a new theory in volunteer management study. This is seen as limitation on previous studies, yet, it is suggested that future researcher should also conduct an in-depth study by using inductive reasoning of philosophical assumption

The discussion in this article only a review on literatures and further study is demand for exploration on the real context of event, volunteer authentic experience, sense of community and volunteer management.

\section{REFERENCES}

Andreassen. (2014). Psychometric assessment of workaholism measures. http://doi.org/10.1108/JMP-05-2013-0143

Baker, S. (2006). Sustainability Development. New York: Routledge Taylos \& Francis Group.

C.Smith-Christensen. (2009). Sustainability as a Concept within Events. Event Management and Sustainability. Cambridge, USA: CAB International.

Gallarza, M. G., Arteaga, F., \& Gil-Saura, I. (2013). The value of volunteering in special events: A longitudinal study. Annals of Tourism Research, 40(1), 105-131. http://doi.org/10.1016/j.annals.2012.08.001

Giannoulakis, C., Wang, C.-H., \& Felver, N. (2015). A Modeling Approach to Sport Volunteer Satisfaction. International Journal of Event and Festival Management, 6(3), 182-199. http://doi.org/10.1108/IJEFM-04-2014-0010

Hallmann, K. (2012). Determinants of volunteer motivation and their impact on future voluntary engagement: A comparison of volunteer\&apos;s motivation at sport events in equestrian and handball. International Journal of Event and Festival Management, 3(3), 272-291. http://doi.org/10.1108/17582951211262701

Hede, A.-M., Garma, R., Josiassen, A., \& Thyne, M. (2014). Perceived authenticity of the visitor experience in museums. European Journal of Marketing, 48(7/8), 1395-1412. http://doi.org/10.1108/EJM-12-2011-0771

Kadri, F. L. (2013). Towards compatibility between artificial and psychometric personality models. Kybernetes, 42(3), 497-505. http://doi.org/10.1108/03684921311323716

Kaplanidou, K., \& Vogt, C. (2010). The Meaning and Measurement of a Sport Event Experience Among Active Sport Tourists. Journal of Sport Management, 24(5), 544-566. Retrieved from http://libraryproxy.griffith.edu.au/login?url=http://search.ebscohost.com/login.aspx?direct=tr ue $\& d b=b t h \& A N=53985937 \&$ site $=$ ehost-live $\&$ scope $=$ site

Kim, J.-H., \& Jang, S. (Shawn). (2016). Determinants of authentic experiences. International Journal of Contemporary Hospitality Management, 28(10), 2247-2266. http://doi.org/10.1108/IJCHM06-2015-0284 
INTERNATIONAL JOURNAL OF ACADEMIC RESEARCH IN BUSINESS AND SOCIAL SCIENCES

Vol. 8, No. 11, Nov, 2018, E-ISSN: 2222-6990 @ 2018 HRMARS

Lampinen, M.-S., Viitanen, E. A., \& Konu, A. I. (2015). Sense of community and job satisfaction among social and health care managers. Leadership in Health Services, 28(3), 228-244. http://doi.org/10.1108/LHS-09-2014-0067

Lee, Y., Kim, M., \& Koo, J. (2015). The impact of social interaction and team member exchange on sport event volunteer management. Sport Management Review. http://doi.org/10.1016/j.smr.2016.04.005

Lord, W., \& Lord, W. (1993). The Use of Psychometric Tests in Counselling and Stress Management.

Mykletun, R. J., \& Himanen, K. (2016). Volunteers at biking race events Antecedents of commitment and intention to remain volunteering at future events. Sport, Business and Management: An International Journal, 6(3), 2016. http://doi.org/10.1108/SBM-12-2014-0051

PEMANDU. (2012). ETP Annual Report - Economic Transformation Programme: Malaysia. Retrieved from http://etp.pemandu.gov.my/annualreport2012/

PEMANDU. (2015). Economic Transformation Programme (ETP). Retrieved from http://etp.pemandu.gov.my/

Reid, S. (2011). Event stakeholder management: developing sustainable rural event practices. International Journal of Event and Festival Management, 2(1), 20-36. http://doi.org/10.1108/17582951111116597

Winkle, C. M. Van, \& Woosnam, K. M. (2013). Sense of community and perceptions of festival social impacts. International Journal of Event and Festival Management, 5, 22-38. http://doi.org/10.1108/IJEFM-01-2013-0002 